\title{
HHS Creates New Advisory Board to Improve Biosecurity in 'Dual Use' Research
}

On 4 March, US Department of Health and Human Services (HHS) Secretary Tommy G. Thompson announced the creation of the National Science Advisory Board for Biosecurity (NSABB) to improve biosecurity measures related to so-called 'dual use' research-legitimate biological research that could be misused to threaten public health or national security ${ }^{1}$. The HHS Secretary, with input from directors of other federal departments and agencies, will appoint board members, including up to 25 voting members with specialties ranging from bioethics, to law enforcement, to veterinary medicine. The NSABB will also include nonvoting members representing at least 15 federal departments and agencies.

The NSABB will be managed by NIH and will be expected to advise the Secretary of HHS, the director of NIH, and the heads of federal departments and agencies that conduct or support 'dual use' biomedical research on the following issues:

- "strategies for local and federal biosecurity oversight for all federally funded or supported life sciences research;

- "development of guidelines for biosecurity oversight of life sciences research and [provision of] ongoing evaluation and modification of these guidelines as needed;

- "strategies to work with journal editors and other stakeholders to ensure the development of guidelines for the publication, public presentation and public communication of potentially sensitive life sciences research;

- "development of guidelines for mandatory programs for education and training in biosecurity issues for all life scientists and laboratory workers at federally funded institutions; and

\section{Regulation Updates}

Court Dismisses Suit to Force USDA to Is

On 2 March, the US District Court in Northern California dismissed a lawsuit filed by the Animal Legal Defense Fund (ALDF) and the Animal Welfare Insitute (AWI) to force the US Department of Agriculture (USDA) to issue new Animal Welfare Act regulations to promote the psychological well being of nonhuman primates (NHP) by addressing physical environment, social grouping, enclosures, and other issues ${ }^{2}$. US District Court Judge Phyllis Hamilton agreed with USDA and the National Association for Biomedical Research (NABR) when she ruled that the case lacked merit. Judge Hamilton dismissed the case with prejudice, meaning that the suit cannot be filed again in the United States.

\section{USDA Amends Rules on Blood and Tissue Collection at Slaughtering and Rendering} Establishments

Effective 4 March, USDA amended its regulations "governing interstate transportation of animals to establish requirements for the collection of blood and tissue samples from livestock (horses, cattle, bison, captive cervids, sheep and goats, swine, and other farm-raised animals) and poultry at slaughtering and rendering establishments when it is necessary for disease surveillance ${ }^{3}$."

The amended rule specifies individuals transporting livestock and poultry across state lines can only deliver them to slaughtering or rendering facilities that have been approved by the Animal and Plant Health Inspection Service (USDA APHIS). USDA APHIS will only approve establishments that provide "the type of space and facilities specified by the regulations to safely collect blood and tissue samples for disease testing ${ }^{3}$."

This amended rule is meant to "to improve surveillance programs for animal diseases, to contribute to the eventual control or eradication of such diseases, and to assist in certifying the status of the United States or its regions with regard to freedom from specific animal diseases ${ }^{3}$."

FDA Announces New Rates for Animal Drug Application Fees in FY04

On 18 February, the US Food and Drug Administration (FDA) Center for Veterinary Medicine announced the following rates for animal drug application fees for fiscal year (FY) 2004 (1 September 2003-30 September 2004) and payment procedures for those fees: $\$ 61,000$ for an animal drug application and $\$ 30,500$ for a supplemental animal drug application for which safety or effectiveness data are required ${ }^{4}$.

The Federal Food, Drug, and Cosmetic Act, as amended by the Animal Drug User Fee Act of 2003, Public Law 108-130, authorizes FDA to collect user fees for certain animal drug applications, on certain animal drug products, on certain establishments where such products are made, and on certain sponsors of such animal drug applications and/or investigational animal drug submissions. President Bush signed Public Law 108-199, appropriating FY 2004 animal drug user fee revenues, on 23 January. FDA will issue invoices for fees associated with applications submitted between 1 September 2003 and 31 March 2004.

- "development of a code of conduct for life scientists and laboratory workers that can be adopted by federal agencies as well as professional organizations and institutions engaged in the performance of life sciences research domestically and internationally ${ }^{1}$."

HHS will extend its biosecurity policies internationally on a voluntary and cooperative basis through existing international scientific and health organizations, and other relevant international organizations. Additional information on the NSABB is available at http://www.biosecurityboard. gov.

\section{References}

1. US Department of Health and Human Services. News Release. HHS will lead government-wide effort to enhance biosecurity in "dual use" research. (4 March 2004). http://www.hhs.gov/news/press/2004 pres/20040304.html.

2. National Association for Biomedical Research. News Alert. Court agrees with NABR, dismisses primate case filed by ALDF and AWI. (2 March 2003).

3. USDA APHIS. Final rule. Blood and tissue collection at slaughtering and rendering establishments. Federal Register 69(43), 10137-10151 (4 March 2004).

4. FDA Center for Veterinary Medicine. FDA announces animal drug user fee rates for FY04. (18 February 2004). http://www.fda.gov/cvm/index/updates/fees up.htm. 